\title{
Essential Role of SIRT1 Signaling in the Nucleus Accumbens in Cocaine and Morphine Action
}

\author{
Deveroux Ferguson, ${ }^{1}$ Ja Wook Koo, ${ }^{1}$ Jian Feng, ${ }^{1}$ Elizabeth Heller, ${ }^{1}$ Jacqui Rabkin, ${ }^{1}$ Mitra Heshmati, ${ }^{1}$ William Renthal, ${ }^{2}$ \\ Rachael Neve, ${ }^{3}$ Xiaochuan Liu, ${ }^{1}$ Ningyi Shao, ${ }^{1}$ Vittorio Sartorelli, ${ }^{4}$ Li Shen, ${ }^{1}$ and Eric J. Nestler ${ }^{1}$ \\ ${ }^{1}$ Fishberg Department of Neuroscience and Friedman Brain Institute, Icahn School of Medicine at Mount Sinai, New York, New York 10029, ${ }^{2}$ Department of \\ Psychiatry, University of Texas Southwestern Medical Center, Dallas, Texas 78229, ${ }^{3}$ Department of Brain and Cognitive Sciences, Massachusetts Institute of \\ Technology, Cambridge, Massachusetts 02139, and ${ }^{4}$ Laboratory of Muscle Stem Cells and Gene Regulation, National Institute of Arthritis and \\ Musculoskeletal and Skin Diseases, Bethesda, Maryland 20892
}

Sirtuins (SIRTs), class III histone deacetylases, are well characterized for their control of cellular physiology in peripheral tissues, but their influence in brain under normal and pathological conditions remains poorly understood. Here, we establish an essential role for SIRT1 and SIRT2 in regulating behavioral responses to cocaine and morphine through actions in the nucleus accumbens (NAc), a key brain reward region. We show that chronic cocaine administration increases SIRT1 and SIRT2 expression in the mouse NAc, while chronic morphine administration induces SIRT1 expression alone, with no regulation of all other sirtuin family members observed. Drug induction of SIRT1 and SIRT2 is mediated in part at the transcriptional level via the drug-induced transcription factor $\Delta$ FosB and is associated with robust histone modifications at the Sirt1 and Sirt2 genes. Viral-mediated overexpression of SIRT1 or SIRT2 in the NAc enhances the rewarding effects of both cocaine and morphine. In contrast, the local knockdown of SIRT1 from the NAc of floxed Sirt 1 mice decreases drug reward. Such behavioral effects of SIRT1 occur in concert with its regulation of numerous synaptic proteins in NAc as well as with SIRT1-mediated induction of dendritic spines on NAc medium spiny neurons. These studies establish sirtuins as key mediators of the molecular and cellular plasticity induced by drugs of abuse in NAc, and of the associated behavioral adaptations, and point toward novel signaling pathways involved in drug action.

\section{Introduction}

The nucleus accumbens (NAc), central in the brain's reward circuitry, shows dramatic changes in synaptic function, neuronal morphology, and gene expression after chronic exposure to drugs of abuse. Increasing evidence suggests that aberrant epigenetic regulation is one critical factor underlying pathological responses in animal models of drug addiction and may mediate the longlasting behavioral abnormalities that characterize addiction (Renthal and Nestler, 2008). An attractive feature of epigenetic mechanisms is the ability to rapidly respond, integrate, and process a diverse array of environmental stimuli into stable changes in chromatin structure (Kouzarides, 2007). One major form of chromatin modification is histone acetylation, catalyzed by histone acetyltransferase (HATs) and reversed by histone deacetylases (HDACs). Acetylation of specific lysine residues on histone

Received March 23, 2013; revised Aug. 11, 2013; accepted Aug. 29, 2013.

Author contributions: D.F. and E.J.N. designed research; D.F., J.W.K., J.F., E.H., J.R., and M.H. performed research; W.R., R.N., and V.S. contributed unpublished reagents/analytic tools; D.F., E.H., X.L., N.S., and L.S. analyzed data; D.F. and E.J.N. wrote the paper.

This work was supported by grants from National Institute on Drug Abuse, National Alliance for Research on Schizophrenia and Depression, and the UNCF/MERCK Science Initiative; and in part by the Intramural Research Program of the National Institute of Arthritis and Musculoskeletal and Skin Diseases of the National Institutes of Health.

Correspondence should be addressed to Eric J. Nestler, Fishberg Department of Neuroscience and Friedman Brain Institute, Icahn School of Medicine at Mount Sinai, New York, NY 10029. E-mail: Eric.Nestler@mssm.edu.

DOI:10.1523/JNEUROSCI.1284-13.2013

Copyright $\odot 2013$ the authors $\quad 0270-6474 / 13 / 3316088-11 \$ 15.00 / 0$
$\mathrm{N}$-terminal tails is associated with increased gene transcription and is implicated in addiction-related phenomena (Kumar et al., 2005; Wang et al., 2010; Levin et al., 2011; Rogge and Wood, 2013). Sirtuins (SIRTs) are categorized as class III nicotinamide adenine dinucleotide (NAD)-dependent HDACs, although they deacetylate many nonhistone substrates as well. The most studied sirtuin is SIRT1, which through regulating the acetylation state of several histone and nonhistone proteins is implicated in diverse aspects of cellular physiology (Kaeberlein et al., 1999; Bellet and Sassone-Corsi, 2010; Sassone-Corsi, 2012). SIRT1 preferentially deacetylates histone $\mathrm{H} 3$ on lysines 9 and 14 (H3K9 and H3K14), and histone H4 on lysine 16 (H4K16; Kouzarides, 2007; Michán and Sinclair, 2007). In addition, SIRT1 has been shown to deacetylate certain nonhistone proteins, such as several transcription factors [e.g., nuclear factor $-\kappa \mathrm{B}(\mathrm{NF}-\kappa \mathrm{B})$, several FOXO proteins] and HATs (e.g., p300/CBP-associated factor) (Finkel et al., 2009).

Although most studies of SIRT1 to date have focused on peripheral tissues, more recent evidence suggests that the protein is also important in brain function. SIRT1 regulates neuronal differentiation and prevents neurodegeneration in several mouse models (Kim et al., 2007; Michán and Sinclair, 2007; Donmez et al., 2010). Moreover, SIRT1 is important for maintaining acquisition and consolidation of short- and long-term hippocampusdependent memories (Gao et al., 2010; Michán et al., 2010). In a previous study (Renthal et al., 2009), using genome-wide chromatin immunoprecipitation (ChIP) followed by promoter chip 
analysis (termed "ChIP-chip") methods, we identified SIRT1 and its closely related family member SIRT2 as targets of increased $\mathrm{H} 3$ acetylation in NAc after chronic cocaine administration, and verified the induction of both proteins under these conditions. We also demonstrated that systemic administration of a nonselective pharmacological activator of all sirtuins increases cocaine reward. Here, we follow up on these initial observations by establishing an essential role of SIRT1 and SIRT2 in NAc in controlling both cocaine and morphine reward by use of far more selective tools of viral-mediated gene transfer and genetic mutant mice. We also extend this work by demonstrating the actions of SIRT1 on the molecular and cellular adaptations induced in the NAc by chronic drug exposure.

\section{Materials and Methods}

Animals. C57BL/6 male mice (The Jackson Laboratory), 7-8 weeks old and weighing $25-30 \mathrm{~g}$, were habituated to the animal facility 1 week before use and maintained at $23-25^{\circ} \mathrm{C}$ on a $12 \mathrm{~h}$ light/dark cycle. To induce deletion of the SIRT1 transcript in the NAc, we used mutant mice floxed for the Sirt1 allele, which are fully backcrossed onto C57BL/6 and have been described in detail previously (Li et al., 2007). Mice were sterotaxically injected into the NAc with adeno-associated virus (AAV) vectors (serotype 2) expressing GFP or Cre-GFP between the age of 7 and 10 weeks. All animals had access to food and water ad libitum. All experiments were approved by the Animal Care and Use Committee at Mount Sinai Medical Center.

Drugs. Cocaine- $\mathrm{HCl}$ and morphine- $\mathrm{SO}_{4}$ were obtained from SigmaAldrich or the National Institute on Drug Abuse (Bethesda, MD). Drugs were given as daily intraperitoneal injections for $7 \mathrm{~d}$ at $20 \mathrm{mg} / \mathrm{kg}$. Acute studies consisted of $6 \mathrm{~d}$ of saline injections followed by a single drug injection on the seventh day. Control groups received $7 \mathrm{~d}$ of saline injections. Animals were analyzed at varying times after the last injection.

$R N A$ isolation and PCR. Bilateral 14 gauge NAc punch dissections were obtained from 1-mm-thick coronal brain sections and were frozen immediately on dry ice. Dissections samples were thawed and processed in TriZol (Invitrogen) according to manufacturer guidelines. RNA was isolated and purified using RNeasy Micro columns (Qiagen). We confirmed purity of our samples by spectroscopy at 260/280 and 260/230 >1.8. RNA was reverse transcribed to cDNA using iScript Kit (Bio-Rad). Quantitative PCR (qPCR) was performed using an Applied Biosystems 7500 system. Reactions were run in triplicate and analyzed using the $\Delta \Delta$ Ct method (Livak and Schmittgen, 2001).

Chromatin immunoprecipitation. ChIP was performed for $\Delta \mathrm{FosB}$ as described previously (Kumar et al., 2005), with minor modifications. Briefly, for each ChIP, anterior and posterior bilateral 14 gauge NAc punches were pooled (five animals, 20 NAc punches per sample). Punches were fixed for $10 \mathrm{~min}$ with $1 \%$ formaldehyde and then quenched with $2 \mathrm{M}$ glycine for $5 \mathrm{~min}$. Samples were homogenized using a desktop sonicator at low settings (amplitiude 40\%) two times for $7 \mathrm{~s}$ on ice. Next, samples were sheered using a Diogenode Bioruptor XL at $4^{\circ} \mathrm{C}$ at high sonication intensity for $30 \mathrm{~s}$ on/30 s off for $25 \mathrm{~min}$, followed by $25 \mathrm{~min}$ of rest and an additional $25 \mathrm{~min}$ of sonication. Fragment size of 250-1000 bp was verified with an Agilent Bioanalyzer. Before sonication of samples, magnetic sheep anti-rabbit or anti-mouse beads (Invitrogen) were prepared with the respective antibody of interest at $4^{\circ} \mathrm{C}$ overnight on a rotator. Following washing of the magnetic bead/antibody complex, 7.5 $\mathrm{mg}$ (magnetic bead/antibody complex) was added to $400 \mu \mathrm{l}$ of sheared chromatin for histone ChIPs, or $1000 \mu \mathrm{l}$ for $\Delta$ FosB or other nonhistone protein ChIPs, for $16 \mathrm{~h}$ at $4^{\circ} \mathrm{C}$. Eighty microliters of each sample of sheared chromatin was used as an input control. Samples were washed with $\mathrm{LiCl}$ and Tris-EDTA buffers. Reverse cross-linking was performed at $65^{\circ} \mathrm{C}$ overnight, and proteins were removed with proteinase $\mathrm{K}$ (Invitrogen). DNA was purified using a DNA purification kit (Qiagen). Additionally, a normal IgG control was performed to test for nonspecific binding.

ChIP-Seq. Animals were treated with chronic cocaine administration $(20 \mathrm{mg} / \mathrm{kg}$ ) daily for $7 \mathrm{~d}$, and $24 \mathrm{~h}$ later NAc tissue pooled from approx- imately five mice was processed for ChIP as described previously (Renthal et al., 2009; Maze et al., 2010). Antibodies were all ChIP grade from Abcam. Approximately 10 ng of input DNA or pull-down DNA was used for the preparation of sequencing libraries following the instructions of the Illumina ChIP-Seq Sample Prep Kit (catalog \#IP-102-1001). In brief, DNA fragment overhangs were converted into phosphorylated blunt ends using T4 DNA polymerase, Klenow polymerase, and T4 polynucleotide kinase. An " $\mathrm{A}$ " base was then added to the DNA fragments to enable ligation to the adapters, which have a single " $\mathrm{T}$ " overhang. The libraries were analyzed on a $2 \%$ agarose gel, and size was selected between 175 and $300 \mathrm{bp}$. Gel-extracted DNA was further enriched by PCR and run on a bioanalyzer to validate size distribution and concentration. All libraries were sequenced on Illumina Hi-Seq 2000 machines at Mount Sinai Hospital and were analyzed according to published methods (Maze et al., 2011; Shen et al., 2013).

Immunoblotting. Mice were given a lethal dose of chloral hydrate, then sequentially perfused with PBS and $4 \%$ paraformaldehyde. Brains were incubated in a $30 \%$ sucrose solution overnight at $4^{\circ} \mathrm{C}$ and sectioned at 35 $\mu \mathrm{m}$ on a microtome (Leica). Free-floating sections were washed with PBS, then blocked (donkey serum), and later incubated with anti-GFP (rabbit polyclonal, 1:200; Invitrogen) and/or anti-SIRT1 (rabbit polyclonal 1:500; Millipore). After $4^{\circ} \mathrm{C}$ overnight incubation with constant agitation, sections were washed and incubated with Cy2 and/or Cy3 fluorescent antibodies for $2 \mathrm{~h}$ at room temperature, after which they were washed, step grade ethanol dehydrated, and mounted with DPX. Sections were then analyzed using confocal microscopy with a Carl Zeiss 560LSM instrument at various magnifications. Immunoblotting was performed using standard procedures on NAc punch dissections from individual animals (Maze et al., 2010). Final blots were developed by chemiluminescence analysis using supersignal dura ECL (Pierce Biotechnology/Thermo Fisher Scientific). Images were quantified using densitometry (ImageJ, NIH), and samples were normalized using GAPDH or $\beta$-tubulin.

Viral-mediated gene transfer. Mice were anesthetized with a ketamine/ xylazine cocktail (ketamine $100 \mathrm{mg} / \mathrm{kg}$ and xylazine $10 \mathrm{mg} / \mathrm{kg}$ ) and prepared for sterotaxic surgery. Thirty-three gauge syringe needles (Hamilton) were used to bilaterally infuse $0.5 \mu \mathrm{l}$ of virus into NAc at a rate of $0.1 \mu \mathrm{l} / \mathrm{min}$ at $1.6 \mathrm{~mm}$ anteroposterior, $+1.5 \mathrm{~mm}$ lateral, and 4.4 $\mathrm{mm}$ dorsoventral from bregma. We used bicistronic p1005 herpes simplex virus (HSV) vectors expressing GFP alone or GFP plus SIRT1, SIRT2, or a CreGFP fusion protein. In this system, GFP expression is driven by a cytomegalovirus promoter, whereas the select gene of interest is driven by the IE4/5 promoter (Maze et al., 2010). In some experiments, we used AAV vectors serotype 2 expressing GFP or CreGFP as described previously (Maze et al., 2010).

Conditioned place preference. Conditioned place preference (CPP) was performed as described previously (Maze et al., 2010). Briefly, animals were first prescreened in a photobeam-monitored box to detect any baseline bias to the two chambers of the CPP apparatus. Mice that showed a statistically significant preference to one of the two chambers were removed from further analysis ( $<10 \%$ of all animals). Mice were then divided into control and experimental groups with equivalent pretest scores. During the training phase, animals were injected with saline in the morning and placed in one chamber for $30 \mathrm{~min}$, then were injected with cocaine ( $5-15 \mathrm{mg} / \mathrm{kg}$, i.p.) and placed in the other chamber in the afternoon. This training regimen was conducted for $2 \mathrm{~d}$ followed by a test day in which mice were placed back into the apparatus without treatment for $20 \mathrm{~min}$ and evaluated for chamber preference. For all groups, baseline locomotion in response to saline was assessed. CPP scores were calculated by subtracting time spent in the saline-paired chamber from time spent in the cocaine-paired chamber. Please note that different drug doses were used depending on the experimental conditions: lower doses were used for experiments in which the manipulation was predicted to enhance CPP to avoid ceiling effects, and higher doses were used for experiments in which the manipulation was predicted to reduce CPP to avoid floor effects.

Locomotor sensitization. Locomotor sensitization was measured per published protocols (Lobo et al., 2010) with minor modifications. Activity was assessed in the $x$ - and $y$-planes for horizontal ambulations in a 75 
$\mathrm{cm}^{2}$ chamber using EthoVision XT. On days 1-7, mice were first habituation to the apparatus for $5 \mathrm{~min}$ then injected intraperitoneally with saline, and $10 \mathrm{~min}$ later they were injected with saline or cocaine (7.5 $\mathrm{mg} / \mathrm{kg}$ ) and analyzed for $30 \mathrm{~min}$. Seven days after the last saline/cocaine injection, they were given a challenge injection of cocaine and again tested for locomotor activity.

Statistical analysis. One- and two-way ANOVAs were performed to determine significance for conditions in which there were more than two groups or two factors. Unpaired Student's $t$ test with a two-tailed $p$ value were used for other comparisons including qPCR, CPP, and Western blotting, comparing HSV-GFP to HSV-Cre in Sirt1 floxed mice, and ChIP experiments. All values included in the figure legends represent means \pm SEM.

\section{Results}

\section{Drugs of abuse induce SIRT1 and SIRT2 expression in the NAc}

As a first step to explore the role of sirtuins in drug action, we analyzed mRNA expression levels of all SIRT family members in mouse NAc after acute or chronic (7 d) exposure to cocaine or morphine, with animals analyzed $24 \mathrm{~h}$ after the last drug dose. As shown in Figure 1A, chronic cocaine induces Sirt1 and Sirt2 mRNA levels in NAc, whereas chronic morphine induces Sirt1 only, with no changes seen in all other sirtuins. These effects were regionally specific as we did not observe any significant changes in the dorsal striatum (data not shown). To define the temporal pattern of SIRT regulation, we collected NAc from animals treated chronically with cocaine or morphine at several time points after the last drug dose. While the chronic cocaineinduced increase in Sirt1 and Sirt2 mRNA levels were apparent at 4 and $24 \mathrm{~h}$ with no change seen at the $1 \mathrm{~h}$ time point (Fig. $1 B$ ), the chronic morphine-induced increase in Sirt 1 was apparent at $24 \mathrm{~h}$ only (Fig. 1C). We also found that the cocaine- and morphineinduced increase in Sirt1 expression, but not Sirt2 expression, was relatively long lived: increased Sirt1 mRNA levels persisted through $5 \mathrm{~d}$ of withdrawal and reverted to control levels by day 10 (Fig. 1B,C). Western blot analysis demonstrated that similar drug regulation was seen at the level of SIRT1 and SIRT2 protein. At the $24 \mathrm{~h}$ time point, chronic administration of cocaine or morphine increased levels of SIRT1 protein in NAc, whereas only cocaine increased levels of SIRT2 protein (Fig. 1D,E). In contrast, we observed no change in Sirt1 or Sirt 2 mRNA or protein levels at either 4 or $24 \mathrm{~h}$ after single doses of cocaine or morphine (Fig. $1 F, G$ ), indicating that repeated exposure is required for induction of these genes.

Next, to gain insight into whether drug regulation of SIRT expression in NAc is achieved at the transcriptional level, we took advantage of large ChIP-Seq datasets for several chromatin marks in NAc of mice treated chronically with cocaine or saline and examined $24 \mathrm{~h}$ after the last treatment. Mining these existing data for changes that occur with cocaine at the Sirt1 gene, we found changes consistent with transcriptional activation: increased binding of a mark associated with active gene expression such as trimethylation of lysine 4 of $\mathrm{H} 3$ (H3K4me3), and no changes in marks associated with gene repression such as dimethylation and trimethylation of lysine 9 of H3 (H3K9me2 and H3K9me3; Fig. $1 H$ ). These observations support the hypothesis that cocaine induction of SIRT1 is mediated via transcriptional mechanisms.

\section{Mechanisms underlying SIRT1 and SIRT2 induction in the NAc}

Based on these findings, we studied the upstream transcriptional mechanisms mediating cocaine and morphine induction of SIRT1 and SIRT2. $\triangle$ FosB, a Fos family transcription factor that binds to activator protein 1 (AP1) sites in responsive genes, is well characterized for its role in NAc in addiction-related behaviors (Nestler, 2008; Robison and Nestler, 2011). $\Delta$ FosB is a highly stable protein and, once induced, persists in NAc for several weeks. A previous ChIP-chip study showed significant enrichment of $\Delta$ FosB binding to the Sirt2 gene promoter in NAc of mice treated chronically with cocaine, with no change apparent at the Sirt1 gene (Renthal et al., 2009). However, ChIP-chip is known to lack quantitative power. Thus, to follow up these initial observations, we performed quantitative ChIP ( $\mathrm{qChIP}$ ) and found robust (twofold to threefold) increased binding of $\Delta$ FosB to both the Sirt1 and Sirt2 promoters in NAc after chronic treatment with cocaine, with similar increases in $\Delta$ FosB binding seen for both genes after chronic morphine administration (Fig. 2A). The observation that chronic morphine increases $\Delta$ FosB binding to the Sirt2 promoter, even though it does not increase Sirt2 expression, indicates that other mechanisms are involved (see Discussion).

$\Delta$ FosB acts as a transcriptional activator or repressor depending on the gene to which it binds (McClung and Nestler, 2003; Kumar et al., 2005; Renthal et al., 2008, 2009). To determine the transcriptional effect of $\Delta$ FosB on the Sirt1 gene, we performed a series of studies using AAV or HSV vectors to overexpress either $\Delta$ FosB or a truncated JunD protein (termed " $\Delta$ JunD"), which antagonizes AP1-mediated transcription (Peakman et al., 2003; Winstanley et al., 2007; Nestler, 2008). First, using AAV vectors to bilaterally overexpress $\Delta$ FosB in mouse NAc for 3 weeks (Fig. $2 B$ ), we observed a selective and significant increase in mRNA levels of Sirt1 and Sirt2 (Fig. 2C). Such induction of Sirt1 by $\mathrm{AAV}-\Delta$ FosB was associated with increased binding of $\Delta \mathrm{FosB}$ to its gene promoter (Fig. $2 D$ ), indicating that virally expressed $\Delta$ FosB is functionally active. In contrast, we saw no effect of AAV- $\Delta$ FosB on other sirtuin genes (Fig. $2 E$ ). Additionally, $\Delta$ FosB induction of Sirt1 requires sustained expression of $\Delta$ FosB, since $\Delta$ FosB overexpression with $\mathrm{HSV}$ vectors, which maximally express transgenes for days 1-4 only (Barrot et al., 2002), did not alter Sirt1 levels (Fig. 2C). Next, we overexpressed $\Delta$ JunD in NAc using AAV vectors and found that this manipulation blocked the ability of cocaine to induce Sirt1 in this brain region (Fig. $2 F$ ). Interestingly, $\Delta$ JunD did not block the binding of endogenous $\Delta$ FosB to the Sirt1 promoter (Fig. $2 D$ ), consistent with its known ability to dimerize with $\Delta$ FosB and bind to AP1 elements in responsive genes, but disrupt transcriptional activation due to the lack of its $\mathrm{N}$-terminal transactivation domain (Peakman et al., 2003; Winstanley et al., 2007; Nestler, 2008). Together, these studies demonstrate that $\Delta$ FosB functions as a transcriptional activator at the Sirt1 and Sirt2 genes.

In addition to transcriptional mechanisms, we identified indirect evidence for post-transcriptional and post-translational regulation of SIRT1 in NAc by chronic cocaine and morphine as well. In cell culture systems, SIRT1 expression is enhanced by the RNA binding protein $\mathrm{Hu}$ antigen $\mathrm{R}$ (HuR; also known as ELAV1), a member of the embryonic lethal abnormal vision family of mRNA binding proteins. HuR binds to the 3' UTR of Sirt1 mRNA in cultured cells and increases its half-life by $>8 \mathrm{~h}$ (Sasaki et al., 2006; Abdelmohsen et al., 2007). Interestingly, we found that chronic cocaine and chronic morphine administration increase levels of HuR mRNA and protein in the mouse NAc (Fig. $3 A, B)$. There is also evidence from cell culture systems that SIRT1 is modified by sumoylation-a post-translational modification involving the addition of small ubiquitin-related modifiers (SUMOs) to lysine resides that is implicated in the regulation of several transcriptional repressors (Bossis and Melchior, 2006). SIRT1 is sumoylated at lysine 734 by 

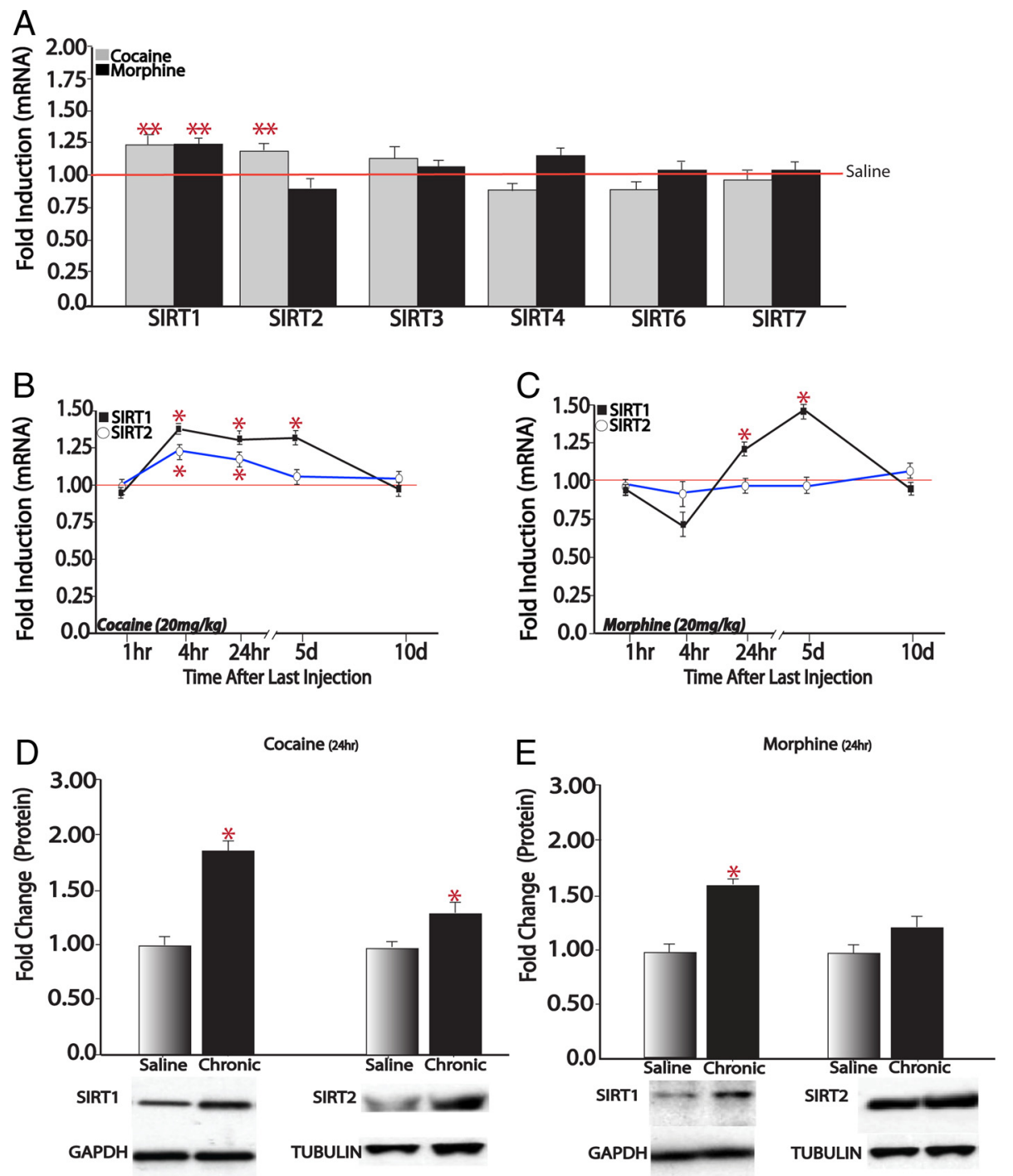

F
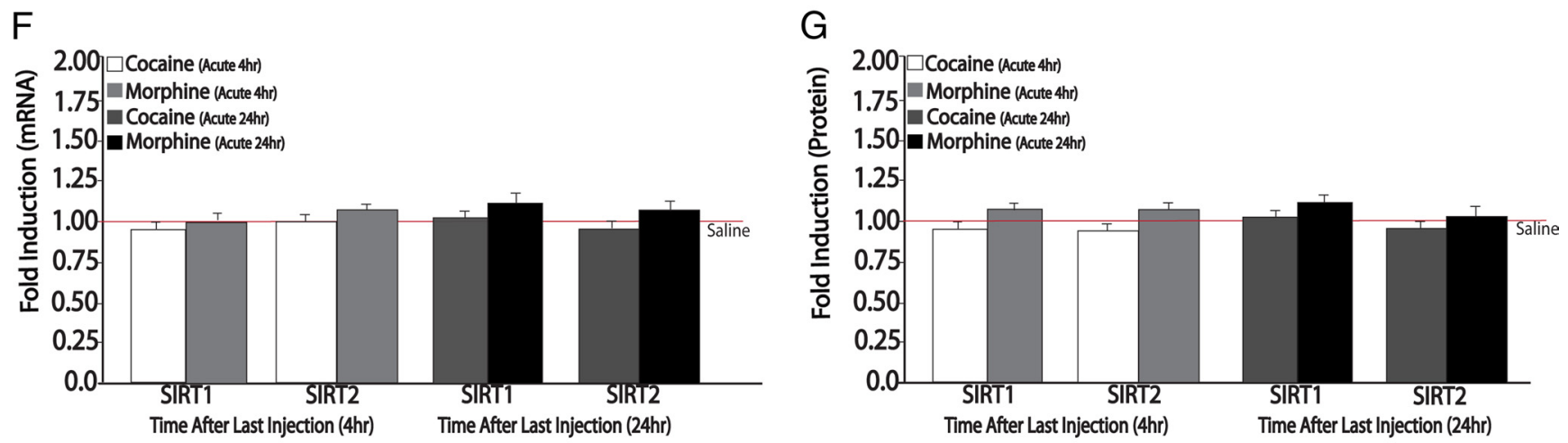

$\mathrm{H}$

ChIP-Seq Analysis of Sirt1

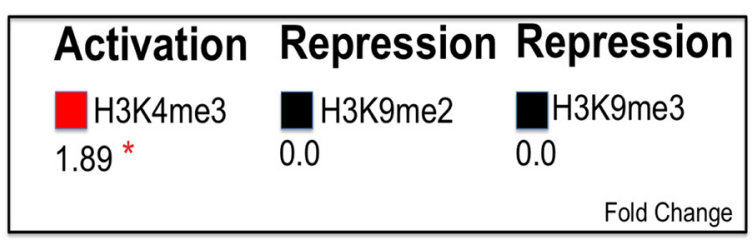

Figure 1. Drugs of abuse induce SIRT expression in NAc. A, qPCR analysis of NAc from chronic ( $7 \mathrm{~d})$ cocaine-treated mice ( $20 \mathrm{mg} / \mathrm{kg}$, i.p.) and chronic ( $7 \mathrm{~d})$ morphine-treated mice ( $20 \mathrm{mg} / \mathrm{kg}$, i.p.), analyzed $24 \mathrm{~h}$ after the last drug dose, revealed increased levels of Sirt $1 \mathrm{mRNA}$ after cocaine $(n=9-10)$ or morphine $(n=8)$ administration. Sirt2 mRNA was increased by (Figure legend continues.) 
A

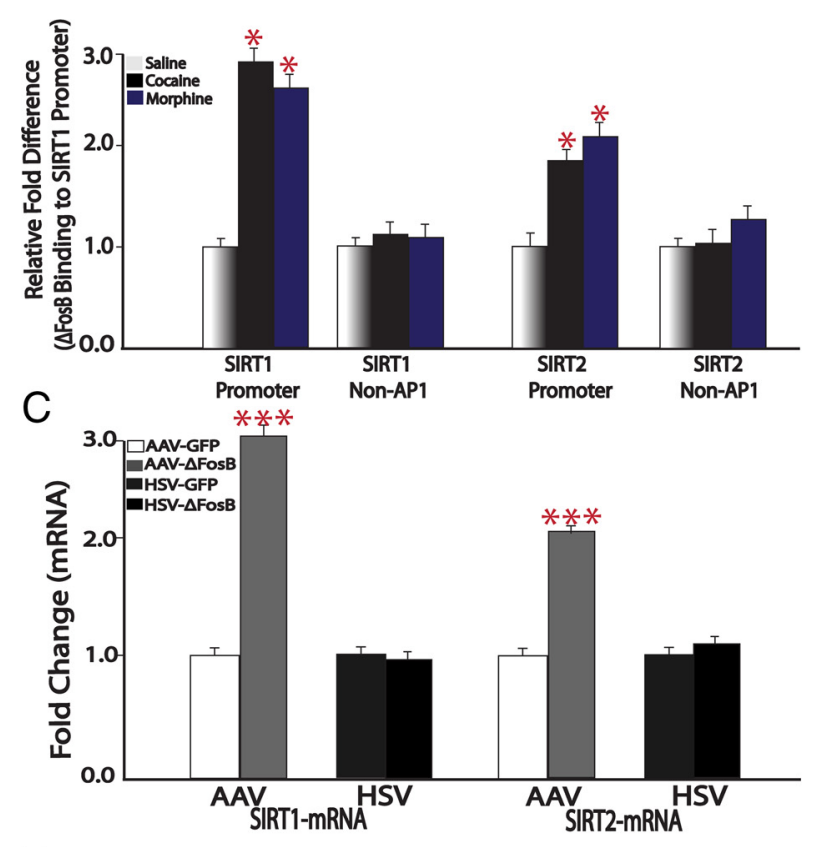

$\mathrm{E}$

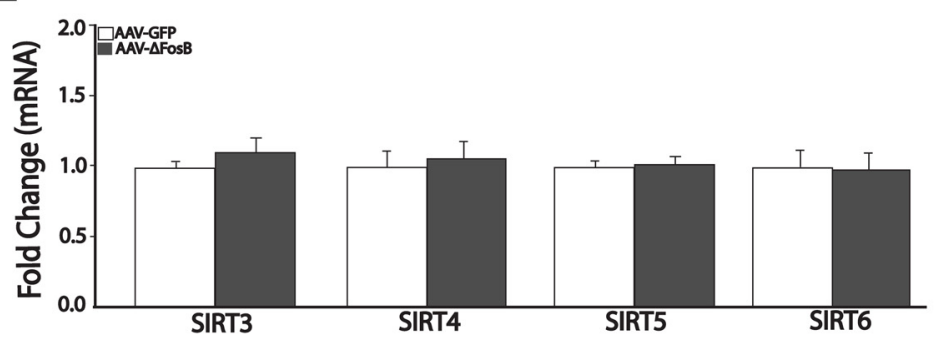

B

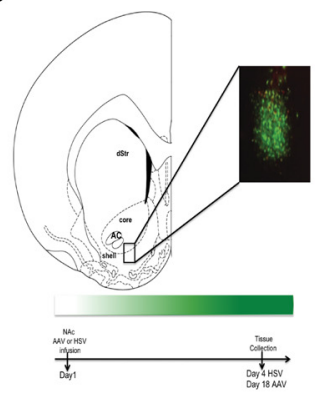

$\mathrm{D}$
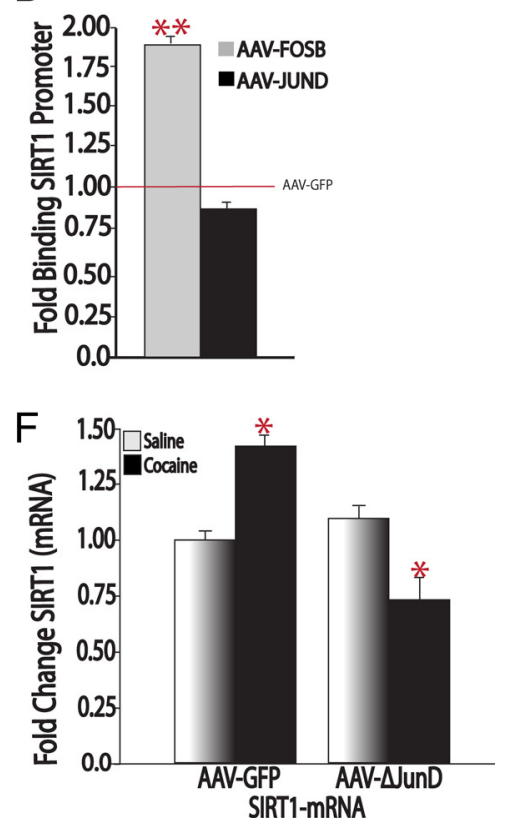

Figure 2. Role of $\Delta$ FosB in Sirt1 and Sirt2 induction in NAc by cocaine and morphine. $A, q$ ChIP reveals increased binding of $\triangle$ FosB to the Sirt1 and Sirt2 gene promoters in the NAc of mice treated for $7 \mathrm{~d}$ with cocaine or morphine $\left(20 \mathrm{mg} / \mathrm{kg}\right.$, i.p.) analyzed $24 \mathrm{~h}$ after the last injection $\left({ }^{*} p<0.05 ; n=6-8\right)$. $\boldsymbol{B}$, Representative image of GFP coexpressed with transgene in NAc. The area of infection was limited to the dorsomedial region of NAc including both shell and core. Time course of viral vector expression: AAV reaches maximal expression $10-14$ d postinfusion and is maintained thereafter, consistent with previous studies (Zachariou et al., 2006; Winstanley et al., 2007). C, Sustained AAV-mediated overexpression of $\Delta$ FosB in NAc induces Sirt1 mRNA $(n=7-8)$ and Sirt2 mRNA $(n=7)$, whereas shorter-term HSV-mediated overexpression does not $(n=7-8)$. D, AAV- $\Delta$ FosB increases $\Delta$ FosB binding to the Sirt1 promoter $(n=7)$, while AAV- $\Delta$ JunD had no effect $(n=7)$. $\boldsymbol{E}, \mathrm{AAV}-\Delta$ FosB had no effect on other sirtuins $(n=7-8)$. $\boldsymbol{F}, 0$ verexpression of $\Delta$ JunD blocks cocaine's induction of Sirt $1(n=$ 5-9). ${ }^{*} p<0.05,{ }^{* *} p<0.01,{ }^{* * *} p<0.001$.

SUMO-1, which results in an increase in SIRT1's deacetylase activity (Yang et al., 2007). We found that chronic cocaine and chronic morphine administration induce both mRNA and protein levels of SUMO-1 in the mouse NAc (Fig. 3C,D). These findings raise the possibility that drugs of abuse might also regulate SIRT1 mRNA translation and catalytic activity to

\section{$\leftarrow$}

(Figure legend continued.) cocaine only ( $n=7-9)$. Sirt3 to Sirt7 were not regulated by either drug of abuse $(n=7-10)$. $B$, Chronic cocaine increases Sirt1 levels $4 \mathrm{~h}(n=6), 24 \mathrm{~h}(n=$ $9-10)$, and $5 \mathrm{~d}(n=8)$ after the last 7 dinjection, with no change seen at $1 \mathrm{~h}$ or $10 \mathrm{~d}(n=6-8)$. A similar pattern holds for Sirt2, with small but significant induction apparent at 4 and $24 \mathrm{~h}$ ( $n=$ $8-9)$.C, Chronic morphine increases Sirt 7 levels at $24 \mathrm{~h}$ and $5 \mathrm{~d}(n=8)$, with no regulation seen for Sirt2 $(n=8)$. $\boldsymbol{D}, \boldsymbol{E}$, Western blotting reveals that chronic cocaine or chronic morphine administration increased SIRT1 and chronic cocaine administration increased SIRT2 protein levels at the $24 \mathrm{~h}$ time point $(n=5-10) . \boldsymbol{F}, \mathbf{G}$, A single dose of cocaine or morphine had no effect on Sirt1 or Sirt2 mRNA levels $(\boldsymbol{F})$ or protein levels $(\boldsymbol{G})$ at either 4 or $24 \mathrm{~h}(n=8-10)$. $\boldsymbol{H}$, ChIP-Seq analysis of chromatin marks in NAc after chronic cocaine exposure reveals increased binding of marks associated with gene activation (e.g., H3K4me3), with no changes in binding of repressive marks (H3K9me2 and H3K9me3). ${ }^{*} p<0.05,{ }^{* *} p<0.01$. promote its function, possibilities that now require direct experimentation.

\section{SIRT1 and SIRT2 in the NAc increase behavioral responses to} cocaine and morphine

We previously implicated sirtuins in behavioral responses to cocaine by use of broadly acting and nonspecific pharmacological agents, some of which were given systemically and hence affected sirtuin activity in all tissues and brain regions (Renthal et al., 2009). To directly test the specific involvement of SIRT1 and SIRT2 in the NAc in behavioral responses to cocaine and morphine, we used HSV vectors to overexpress SIRT1 or SIRT2 in mouse NAc and assessed CPP, an indirect measure of reward, to these drugs. First, immunohistochemical analysis confirmed the targeting of medium spiny neurons in NAc after bilateral infusion of HSV vectors; expression was circumscribed within the dorsomedial part of NAc including portions of both shell and core (Fig. 4A). To further validate the HSV-SIRT1 vector, we assessed acetylation levels of several histone and nonhistone substrates for SIRT1 in other tissues (Finkel et al., 2009; Fig. 4B). 

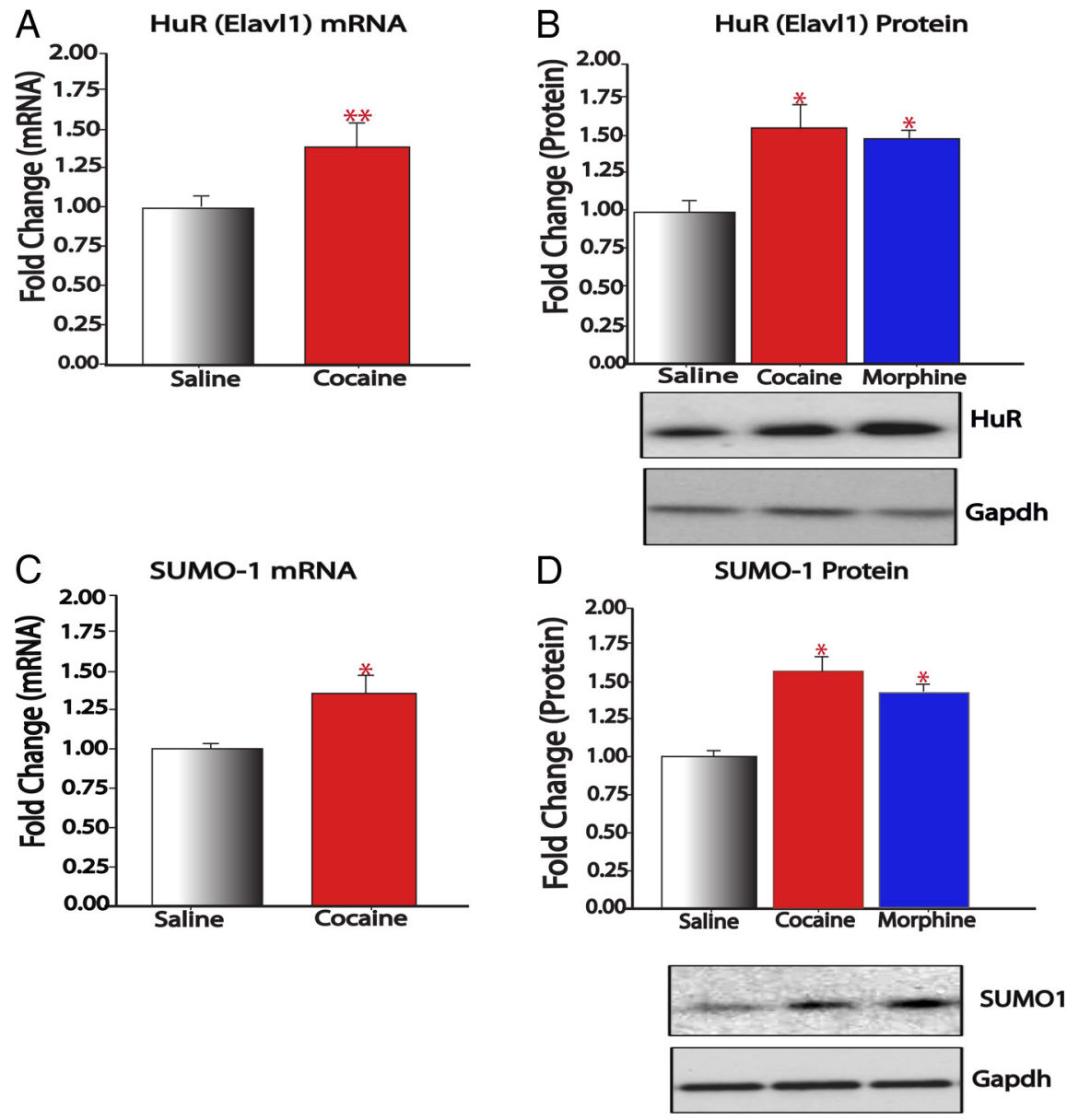

Figure 3. Regulation of post-transcriptional and post-translational modulators of SIRT1. $A, B$, Chronic (7d) cocaine increases both HuR transcript levels $(\boldsymbol{A} ; n=6-8)$ and protein levels $(\boldsymbol{B} ; n=7)$ in NAc. A similar increase in HuR protein is induced in NAc by chronic morphine $(n=8-10 ; \boldsymbol{B}) . \boldsymbol{C}, \boldsymbol{D}$, Cocaine also increases SUM0-1 transcript levels $(\boldsymbol{C} ; n=6-8)$ and protein levels $(\boldsymbol{D} ; n=$ 7-8). Chronic morphine likewise induces SUM0-1 protein in NAC $(n=8-10 ; \boldsymbol{D}) .{ }^{*} p<0.05,{ }^{* *} p<0.01$.

HSV-SIRT1, which increased SIRT1 protein levels in NAc by approximately twofold, decreased levels of acetyl-H4K16, acetyl-p65 (an NF- $\kappa$ B subunit), and acetyl-FKRH (a FOXO transcription factor), with a trend for decreased global levels of pan-acetyl-H3. In contrast, levels of other SIRT substrates seen in other systems, including acetyl-H3K9, acetyl-H3K56, and acetyl-p53, were unaffected in NAc by SIRT1 overexpression or in some cases showed changes in the opposite direction. These observations support the notion that SIRT might target a partly different set of proteins in NAc compared with other brain regions or peripheral tissues. To determine whether HSV-mediated overexpression of SIRT1 is sufficient to regulate genes known to play a role in synaptic plasticity in the NAc, we treated animals intra-NAc with HSV-GFP or HSV-SIRT1 and assessed gene expression by qPCR $3 \mathrm{~d}$ later, which corresponds to the first day of behavioral testing in the cocaine and morphine CPP paradigm. We observed significant increases in mRNA expression of $B d n f$ (brain-derived neurotrophic factor), Creb1 (cAMP response element binding protein-1), $C b p$ (CREB binding protein), Cdk5 (cyclin-dependent kinase-5), Syn2 (synapsin 2), and Grial (the GluA1 AMPA glutamate receptor subunit) in the NAc of mice overexpressing HSV-SIRT1 relative to the HSV-GFP control group (Fig. 4C).

Having validated the vectors, we proceeded with CPP studies, using an unbiased paradigm in which animals do not prefer a chamber at baseline (Fig. 5A). HSV-SIRT1 increased CPP for cocaine relative to the HSV-GFP control group in a dose-dependent fashion (Fig. $5 B)$. Likewise, animals injected with HSVSIRT1 showed a dose-dependent increase in morphine CPP (Fig. 5C). We observed similar increases in cocaine and morphine CPP when SIRT2 was overexpressed (Fig. $5 D, E$ ). We also explored the effect of SIRT1 on cocaine-induced locomotor sensitization. The acute locomotoractivating effects of cocaine increase with repeated drug exposure; such sensitization is thought to reflect changes in synaptic plasticity and gene expression that contribute to aspects of drug addiction (Robinson and Berridge, 2008). Mice injected with HSV-SIRT1 displayed an enhanced locomotor response to the initial injection of cocaine relative to the HSV-GFP control group (Fig. 5F,G). This effect was specific to cocaine, and was not the result of injection-related stress, because HSV-SIRT1 animals injected with saline did not exhibit an increase in locomotor activity (data not shown). This effect on cocaine responses was transient, as no further enhancement in locomotor sensitization from days 2 to 7 was observed relative to the control group (Fig. 5F). However, after $7 \mathrm{~d}$ of withdrawal, HSV-SIRT1 mice displayed a dramatic enhancement in locomotor sensitization in response to a challenge dose of cocaine when compared with HSV-GFP controls (Fig. $5 F, G)$. These findings further substantiate that SIRT1 induction in NAc promotes behavioral responses to cocaine, and show that even a transient increase in SIRT1 expression, mediated by HSV vectors, can lead to enhanced behavioral responses that persist long after transgene expression reverts to control levels.

To gain insight into the mechanism underlying this sustained effect of HSV-SIRT1, we performed qChIP for SIRT1 at several representative genes in the NAc of mice that had received injections of HSV-GFP or HSV-SIRT1 into this brain region $14 \mathrm{~d}$ earlier. We found a significant increase in SIRT1 binding at the $B d n f$ and $C b p$ genes, and trends for increases at the Cdk5 and Syn 2 genes (Fig. $4 D$ ). These data indicate that a transient increase in SIRT1 levels can lead to more sustained increases in SIRT1 binding to certain target genes, providing one possible mechanism for the sustained behavioral effects observed with HSV-SIRT1.

To investigate whether SIRT1 in NAc is required for normal behavioral responses to drugs of abuse, we injected an AAV vector expressing Cre recombinase or GFP alone specifically into NAc of mice homozygous for a loxP-flanked Sirt1 gene (Li et al., 2007). Eighteen days after AAV injection (when transgene expression is maximal), SIRT1 knockdown was confirmed by immunohistochemistry (Fig. 5H). Using this approach, we observed that animals injected with AAV-Cre displayed decreased preference for cocaine and for morphine at drug doses that produce robust CPP in AAV-GFP control mice (Fig. $5 I, J$ ). These 
data demonstrate that SIRT1 activity in NAc is necessary for enhanced cocaine and morphine reward.

SIRT1 regulates dendritic spine density in the NAc

The findings that SIRT1 is crucial for reward-related behavior and can regulate plasticity-related genes in the NAc prompted us to investigate the possibility that SIRT1 may also regulate dendritic plasticity in this brain region. A large literature has shown that chronic cocaine administration increases dendritic spine density of NAc medium spiny neurons and that this structural plasticity is associated with enhanced behavioral sensitivity to cocaine (Robinson and Kolb, 2004; Kalivas, 2009; Russo et al., 2010). Here, we first showed that chronic treatment with cocaine increased the expression of several genes that have been implicated previously in regulating dendritic morphology and synaptic plasticity in NAc, such as Bdnf, Creb1, Cbp, and Cdk5 (Fig. $6 A$ ). As previously reported using similar treatment conditions (Russo et al., 2009; LaPlant et al., 2010; Maze et al., 2010), we observed a corresponding increase in dendritic spine density of NAc medium spiny neurons of mice treated with chronic cocaine administration (Fig. 6B). HSVmediated overexpression of SIRT1 in this brain region was sufficient to mimic the effects of cocaine by increasing NAc dendritic spine density (Fig. 6C). These results suggest that SIRT1 signaling may be one mechanism underlying cocaineinduced increases in NAc dendritic morphology and expression of plasticityrelated genes.

\section{Discussion}

Drugs of abuse regulate SIRT1 and SIRT2 expression in the NAc

Results of the present study demonstrate an essential role of SIRT1 and SIRT2, class III HDACs, in the actions of drugs of abuse on the NAc reward circuit. Our findings show that drugs of abuse specifically regulate SIRT1 and SIRT2 expression in NAc in a temporally defined manner. While chronic cocaine administration induced both proteins in this brain region, chronic morphine administration induced SIRT1 only. These effects were specific to repeated administration of the drugs, as we did not observe changes with acute cocaine or morphine administration. Importantly, these mRNA changes occurred concomitantly with equivalent increases in SIRT1 and SIRT2 protein. Such induction of the SIRTs was associated with chromatin changes at their gene promoters normally indicative of gene activation. Thus, ChIP-Seq analysis for several types of prominent histone modifications indicated that chronic cocaine administration in-

C
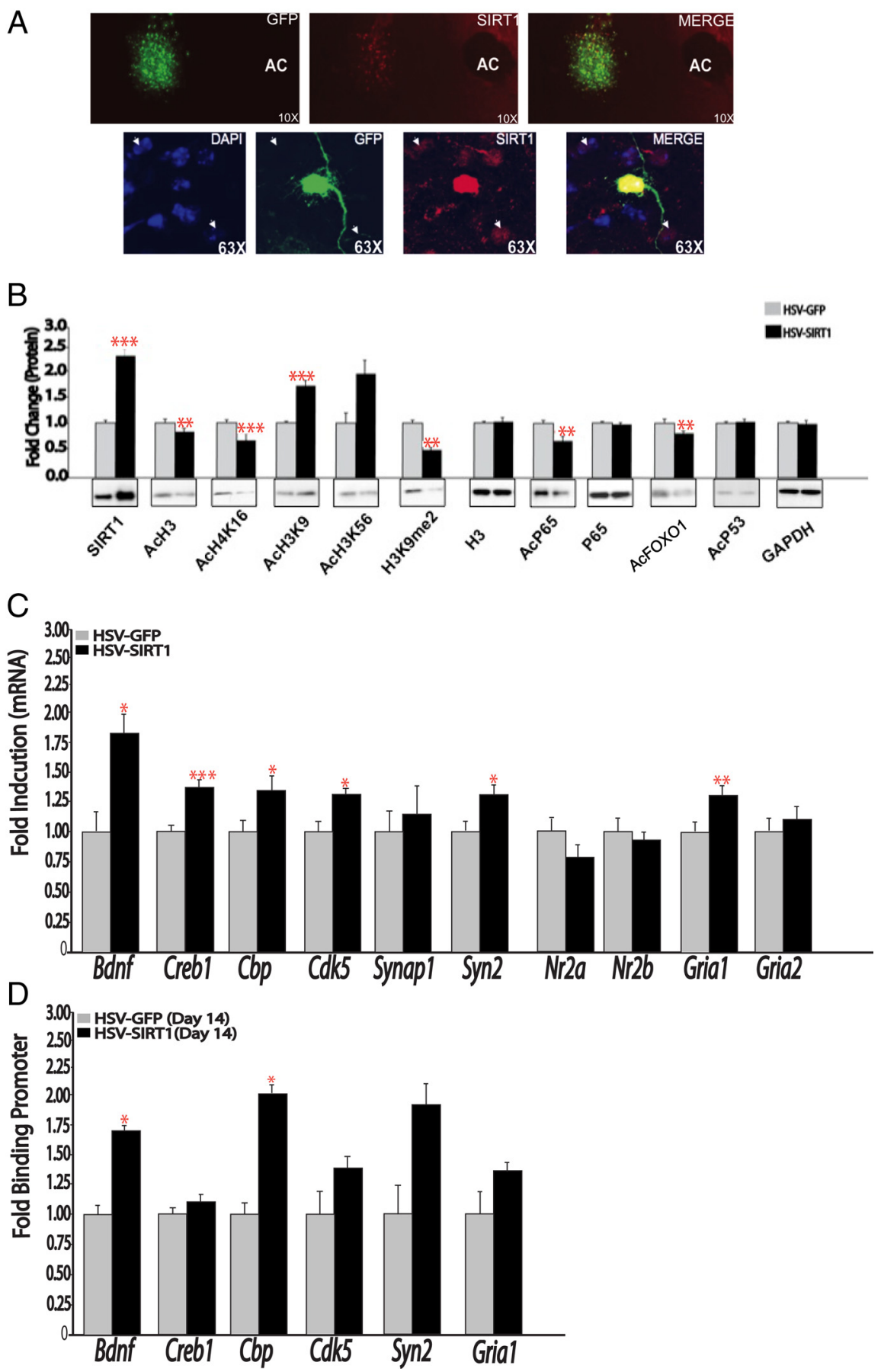

Figure 4. HSV-SIRT1 regulates synaptic plasticity genes. $\boldsymbol{A}$, Double-labeling immunohistochemistry shows robust induction of SIRT1 (red) in neurons infected with HSV-SIRT1 4 d after bilateral HSV vector injections into NAc. $\boldsymbol{B}$, Western blotting reveals that HSV-mediated SIRT1 overexpression in NAc deacetylates certain known histone and nonhistone substrates of SIRT1, but not others ( $n=5-11)$. C, HSV-SIRT1 regulates the expression of certain plasticity-related genes in the NAc. qPCR analysis of mouse NAC overexpressing GFP or SIRT1 ( $n=6-8)$. D, qChIP for Sirt 1 in the NAc of mice injected with HSV-GFP or HSV-SIRT1 and assessed for Sirt 1 binding at the promoter of several plasticity-related genes 14 d later $(n=3-5)$. ${ }^{*} p<0.05,{ }^{* *} p<0.01,{ }^{* *} p<0.001$.

duces an increase in $\mathrm{H} 3 \mathrm{~K} 4 \mathrm{me} 3$ binding at the Sirt1 promoter, with no changes seen in repressive histone methylation (H3K9me2 and H3K9me3). These data extend earlier ChIP-chip findings, which showed increased acetylated $\mathrm{H} 3$ binding on both the Sirt1 and Sirt2 gene promoters as well (Renthal et al., 2009). These data indicate that chronic exposure to drugs of abuse induces SIRT1 (and, for cocaine, SIRT2 as well) in NAc via the transcriptional activation of their genes. Our findings thus add these sirtuins to several other 
A

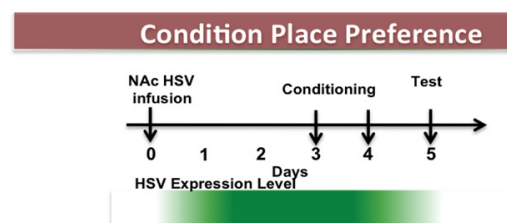

B Cocaine CPP

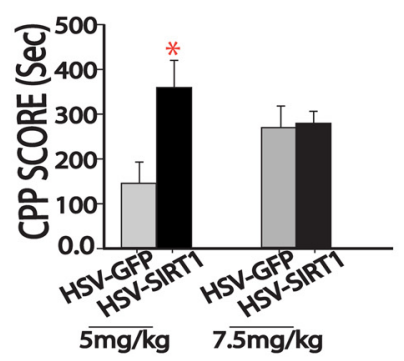

D Cocaine CPP

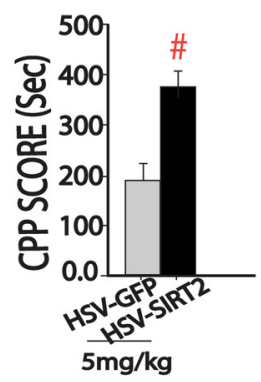

$\mathrm{F}$
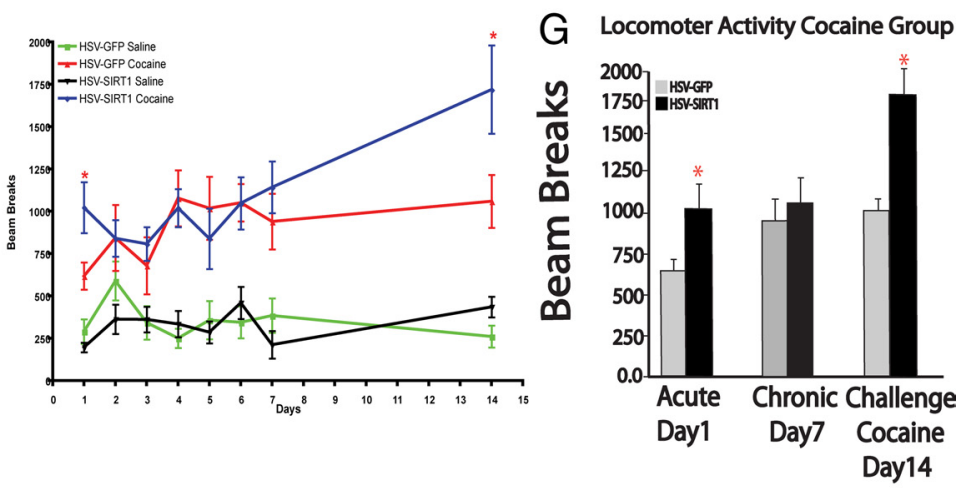

$\mathrm{H}$
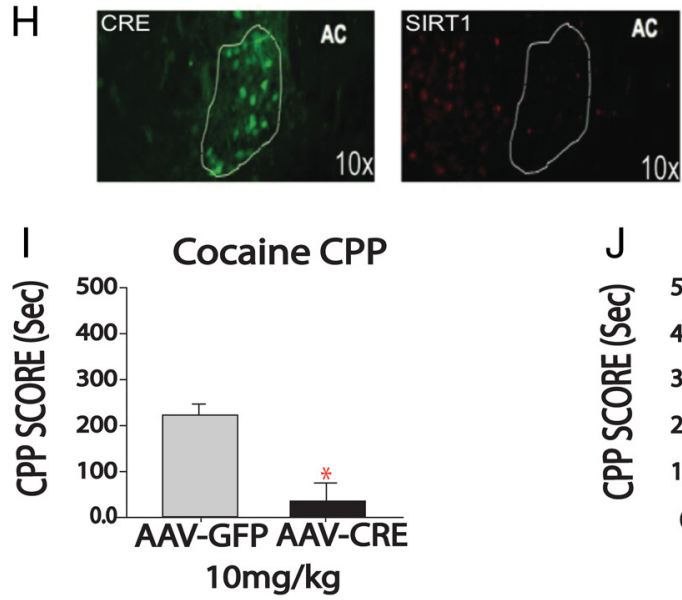
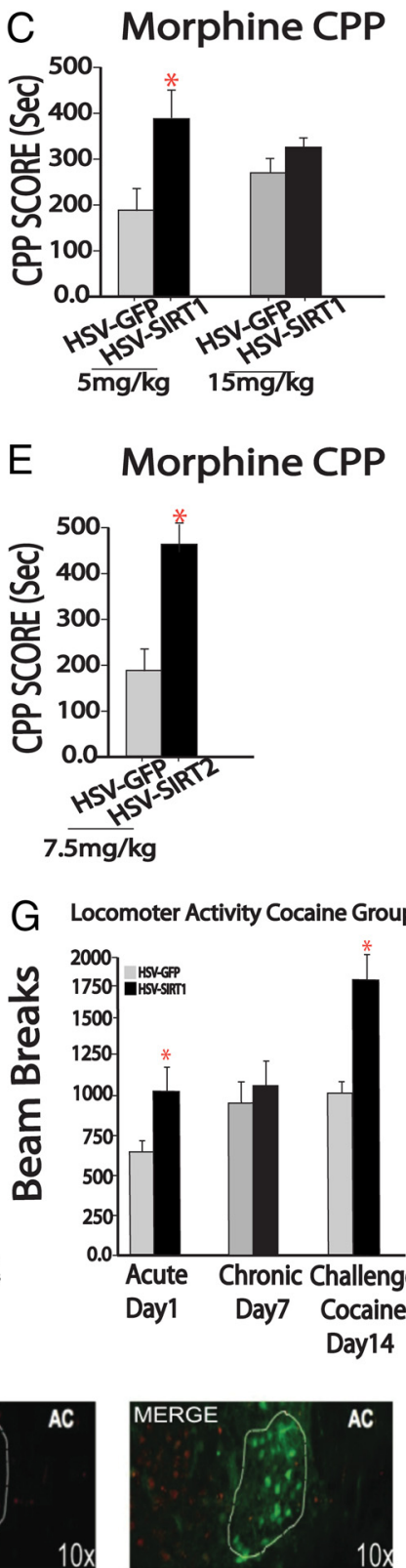

E Morphine CPP
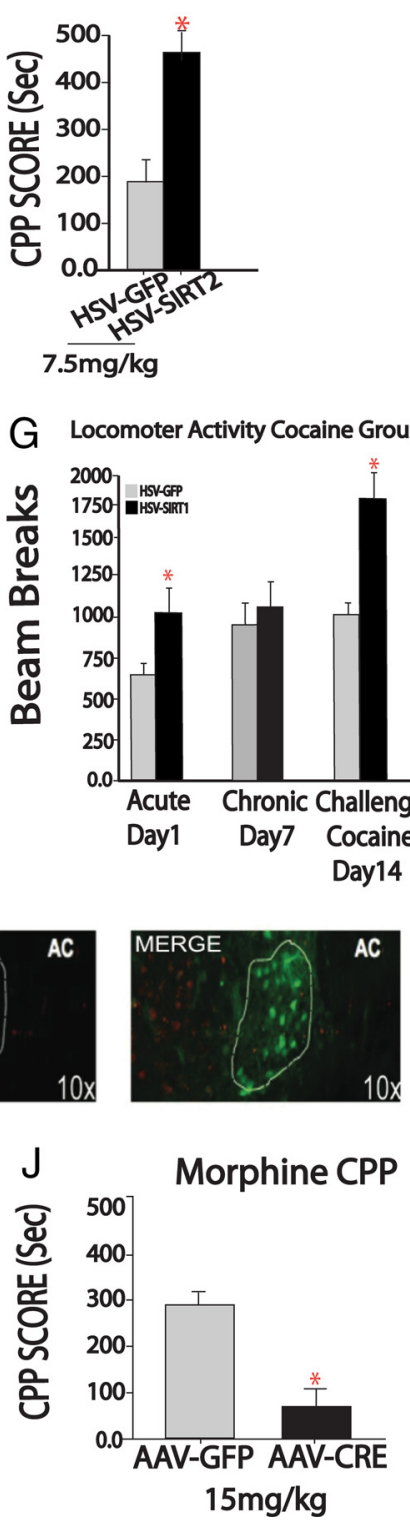

Figure 5. SIRT1 regulates reward-related behaviors. $\boldsymbol{A}$, Temporal expression profile of HSV vectors (based on semiquantitative measures of GFP and transgene expression) and (PP paradigm. Maximal HSV expression occurs within $1 \mathrm{~d}$ postinfusion, continues

chromatin-modifying enzymes, which are also altered in NAc in response to chronic cocaine or morphine exposure, including class I and II HDACs, the histone methyltransferase G9a, and the DNA methyltransferase DNMT3a (Robison and Nestler, 2011; Rogge and Wood, 2013).

\section{Regulatory network controlling SIRT expression}

We investigated potential upstream transcriptional mechanisms underlying the induction of SIRT1 and SIRT2 in NAc by cocaine. We focused on the transcription factor $\Delta$ FosB based on a previous study that found increased $\Delta$ FosB binding to the Sirt2 gene promoter after chronic exposure to cocaine (Renthal et al., 2009). To follow up these findings, we used qChIP to show that chronic cocaine and chronic morphine administration increase $\Delta$ FosB binding to the Sirt1 and Sirt2 promoters in NAc. Since cocaine and morphine are known to induce $\Delta$ FosB in NAc to comparable degrees (Nestler, 2008), it is not surprising that both drugs induce similar increases in $\Delta$ FosB to the two promoters. However, the fact that chronic morphine administration does not also induce Sirt2, despite the increase in $\Delta \mathrm{FosB}$ binding, suggests that morphine, but not cocaine, induces other chromatin changes at the Sirt2 gene, which then oppose $\Delta$ FosB's action, a possibility that now requires investigation. To directly determine whether

\footnotetext{
through day 4 , and dissipates thereafter, consistent with previous studies (Barrot et al., 2002). B, C, Cocaine and morphine CPP was studied after intra-NAc injections of HSV-GFP or HSVSIRT1. Mice expressing HSV-SIRT1 spent more time in the cocaine-paired chamber relative to mice expressing HSV-GFP $(t=2.267, \mathrm{df}=13)$ at a lower but not a higher dose of cocaine. Similar results were seen for morphine $(t=2.276$, $\mathrm{df}=14)$. Cocaine and morphine (PPs in animals overexpressing HSV-SIRT2. D, For cocaine ( $5 \mathrm{mg} / \mathrm{kg})$ CPP, mice expressing HSV-SIRT2 tended to spend more time in the cocaine-paired chamber relative to mice expressing HSV-GFP. E, For morphine $(7.5 \mathrm{mg} / \mathrm{kg})$ CPP, mice expressing HSV-SIRT2 spent more time in the morphine-paired chamber relative to mice expressing HSV-GFP $(t=2.578, \mathrm{df}=13)$. The $7.5 \mathrm{mg} / \mathrm{kg}$ dose was chosen as intermediate between the two doses used for the experiment in $\boldsymbol{E} . \boldsymbol{F}, \boldsymbol{G}, \mathrm{HSV}$-SIRT1 enhances locomotor sensitization to cocaine $(7.5 \mathrm{mg} / \mathrm{kg})$. Acute cocaine administration increases locomotor activity in animals expressing HSV-SIRT1 relative to their GFP controls $(n=7-9)$. Cocaine challenge $(7.5 \mathrm{mg} / \mathrm{kg}) 7 \mathrm{~d}$ after the last chronic cocaine injection increases locomotor activity in animals expressing HSVSIRT1 relative to their GFP controls $(t=2.234, \mathrm{df}=13)$. $\boldsymbol{H}$, Immunohistochemistry shows an ablation of SIRT1 expression in NAc of floxed Sirt7 mice injected intra-NAc with HSV-Cre.I,J, Animals injected with AAV-Cre exhibited decreased CPP for cocaine administration $(10 \mathrm{mg} / \mathrm{kg} ; t=2.399, \mathrm{df}=15)$ and for morphine administration ( $15 \mathrm{mg} / \mathrm{kg} ; t=2.302, \mathrm{df}=13$ ). ${ }^{*} p<0.05$, \#p $<0.09$.
} 
A

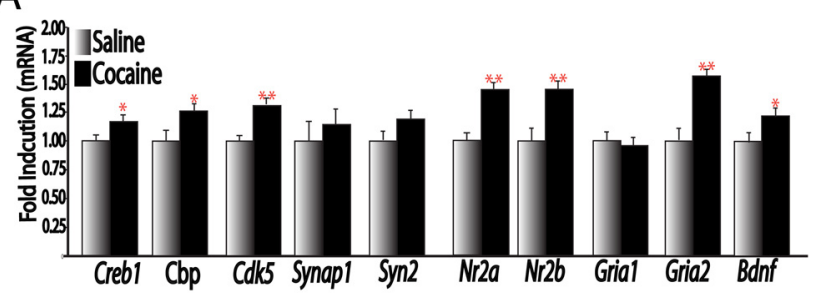

B

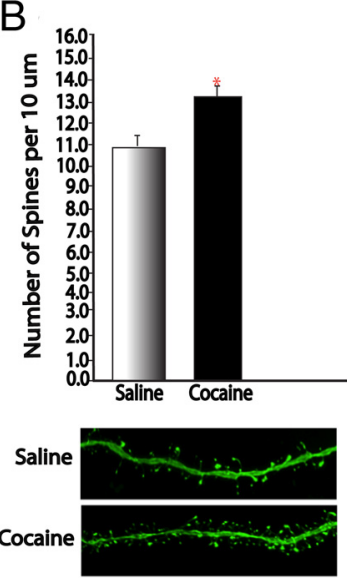

C
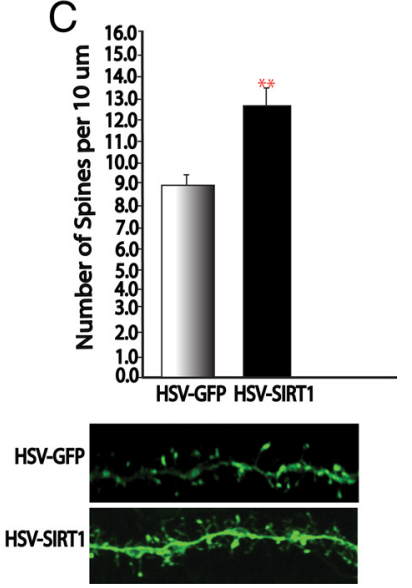

Figure 6. SIRT1 regulates dendritic spine density and expression of plasticity-related genes in NAc. $A, q P C R$ analysis of NAc of mice treated for $7 \mathrm{~d}(20 \mathrm{mg} / \mathrm{kg})$ with cocaine or saline for plasticity-related genes ( $n=7-8) . \boldsymbol{B}, \boldsymbol{C}$, Cocaine increases dendritic spines on NAc medium spiny neurons ( $n=11$ dendrites in $4-5$ animals; $\boldsymbol{B}$ ), an effect mimicked by HSV-SIRT1 ( $n=$ $25-28$ dendrites in $4-5$ animals; $\boldsymbol{C}$. ${ }^{*} p<0.05,{ }^{* *} p<0.01$.

$\Delta$ FosB mediates SIRT1 and SIRT2 induction seen after cocaine exposure, we overexpressed $\Delta$ FosB in NAc using AAV vectors, and observed increases in both SIRT1 and SIRT2 expression levels. In contrast, overexpressing $\Delta \mathrm{JunD}$, a dominant-negative antagonist of $\Delta$ FosB, blocked the induction of SIRT1 by cocaine. Together, these data implicate $\Delta$ FosB as an essential upstream transcriptional regulator of the sirtuin signaling pathway.

Given the diversity of signaling pathways that regulate sirtuins in other experimental systems, we explored whether some of these other mechanisms occur in our drug abuse models. For example, we were interested in sirtuin regulation at the posttranscriptional level, which has gained wide attention as a critical control point in regulating protein availability (Cheadle et al., 2005). Thus, the ubiquitously expressed RNA binding protein HuR contains three RNA recognition motifs that can bind to the 3' UTR of the Sirt1 transcript (Abdelmohsen et al., 2007), which increases its half-life in cultured cells, whereas knockdown of HuR has the opposite effect (Abdelmohsen et al., 2007). We found increased $H u R$ mRNA levels in NAc after chronic cocaine exposure by qPCR on independent tissue samples, which were shown at the protein level after chronic cocaine or morphine administration via Western blotting. We also explored the possibility that cocaine might regulate SIRT1 posttranslationally by analyzing the expression of SUMO-1, which is reported in other systems to enhance the catalytic activity of SIRT1 (Yang et al., 2007). We discovered that chronic cocaine exposure increases SUMO-1 expression in NAc at both the mRNA and protein levels, an effect shown for chronic morphine exposure as well. These findings support the speculation that, in addition to the $\Delta$ FosB-mediated increase in Sirt 1 transcription after chronic drug exposure, the increase in $\mathrm{HuR}$ and SUMO-1 might, respectively, stabilize the Sirt1 transcript and

increase SIRT1 deacetylase activity. While further work is required to directly study these possibilities, our results-by demonstrating robust cocaine and morphine regulation of $\mathrm{HuR}$ and SUMO-1 expression in NAc-implicate these proteins in drug action for the first time.

\section{Sirtuins regulate behavioral responses to cocaine and morphine}

To directly test the influence of SIRT1 and SIRT2 induction in the NAc on behavioral responses to the drugs, we overexpressed either sirtuin in this brain region with HSV vectors or, conversely, we reduced SIRT1 levels locally in NAc using AAV-Cre in floxed Sirt1 mice, and assessed cocaine and morphine CPPs. We found that overexpression of SIRT1 or SIRT2 in NAc enhances both cocaine and morphine CPPs, whereas local knockdown of SIRT1 in NAc attenuates cocaine and morphine reward. We also found that SIRT1 overexpression in NAc enhances locomotor responses to cocaine. These observations are consistent with our earlier report that systemic administration of a nonselective activator of sirtuins promotes behavioral responses to cocaine (Renthal et al., 2009), and specifically implicates regulation of SIRT1 and SIRT2, acting in NAc per se, in mediating these effects. These behavioral actions of SIRT1 and SIRT2 are consistent with extensive work showing that $\Delta$ FosB induction in NAc likewise enhances behavioral responses to drugs of abuse (Nestler, 2008).

\section{SIRT1 regulates dendritic spine density and expression of plasticity-related genes in NAc}

A prominent neural adaptation linked to enhanced behavioral responses to cocaine is an increase in the density of dendritic spines on NAc medium spiny neurons (Robinson and Kolb, 2004; Kalivas, 2009; Russo et al., 2010). Further strengthening our hypothesis that SIRT1 is an essential regulator of cocaine-mediated plasticity, we found that overexpression of SIRT1 is sufficient to induce an increase in dendritic spines on NAc neurons. This increase in dendritic spine density in NAc when SIRT1 is overexpressed complements the observation that knockout of SIRT1 decreases dendritic arborizations and spine density in hippocampus (Michán et al., 2010). In concert with the induction of NAc dendritic spine density by SIRT1 is the induction of numerous plasticity-related genes that have been associated with cocaine regulation of synaptic function. Further work is now needed to directly study the involvement of these various genes in mediating the behavioral and structural adaptations of SIRT1. However, it should be noted that, while most studies correlate increased NAc spine density with sensitized behavioral responses to cocaine (Robinson and Kolb, 2004; Russo et al., 2009; Maze et al., 2010; Dietz et al., 2012; Robison et al., 2013), several studies have found opposite effects (Russo et al., 2010), which highlights the need for additional research in this area. Another major paradox in the field is the observation that chronic administration of morphine or other opiates decreases the density of dendritic spines on NAc medium spiny neurons despite the fact that these drugs, like cocaine, produce enhanced reward and locomotor responses (Robinson and Kolb, 2004; Russo et al., 2010). While current efforts are aimed at understanding this paradox, our data would suggest that mechanisms independent of SIRT1 mediate the structural plasticity to opiates.

\section{Conclusions}

The results of the present study demonstrate the concerted induction of sirtuin activity in the NAc in response to chronic cocaine or morphine administration, and establish that such induction in turn feeds back to enhance an animal's behavioral 
responses to the drugs. These findings contribute to our understanding of the pathophysiology of addiction, and raise the possibility that the host of pharmacological agents being developed to target sirtuins warrant investigation as novel treatment agents for addiction syndromes.

\section{Notes}

Supplemental material for this article is available at http://neuroscience.mssm. edu/nestler/nidappg/chromatingenedatabase.html. This represents the ChIPSeq dataset. This material has not been peer reviewed.

\section{References}

Abdelmohsen K, Pullmann R Jr, Lal A, Kim HH, Galban S, Yang X, Blethrow JD, Walker M, Shubert J, Gillespie DA, Furneaux H, Gorospe M (2007) Phosphorylation of HuR by Chk2 regulates SIRT1 expression. Mol Cell 25:543-557. CrossRef Medline

Barrot M, Olivier JD, Perrotti LI, DiLeone RJ, Berton O, Eisch AJ, Impey S, Storm DR, Neve RL, Yin JC, Zachariou V, Nestler EJ (2002) CREB activity in the nucleus accumbens shell controls gating of behavioral responses to emotional stimuli. Proc Natl Acad Sci U S A 99:11435-11440. CrossRef Medline

Bellet MM, Sassone-Corsi P (2010) Mammalian circadian clock and metabolism - the epigenetic link. J Cell Sci 123:3837-3848. CrossRef Medline

Bossis G, Melchior F (2006) SUMO: regulating the regulator. Cell Div 1:13. CrossRef Medline

Cheadle C, Fan J, Cho-Chung YS, Werner T, Ray J, Do L, Gorospe M, Becker KG (2005) Stability regulation of mRNA and the control of gene expression. Ann N Y Acad Sci 1058:196-204. CrossRef Medline

Dietz DM, Sun H, Lobo MK, Cahill ME, Chadwick B, Gao V, Koo JW, MazeiRobison MS, Dias C, Maze I, Damez-Werno D, Dietz KC, Scobie KN, Ferguson D, Christoffel D, Ohnishi Y, Hodes GE, Zheng Y, Neve RL, Hahn KM, et al. (2012) Essential for Racl in cocaine-induced structure plasticity of nucleus accumbens neurons. Nat Neurosci 15:891-896. CrossRef Medline

Donmez G, Wang D, Cohen DE, Guarente L (2010) SIRT1 suppresses betaamyloid production by activating the alpha-secretase gene ADAM10. Cell 142:320-332. CrossRef Medline

Finkel T, Deng CX, Mostoslavsky R (2009) Recent progress in the biology and physiology of sirtuins. Nature 460:587-591. CrossRef Medline

Gao J, Wang WY, Mao YW, Gräff J, Guan JS, Pan L, Mak G, Kim D, Su SC, Tsai LH (2010) A novel pathway regulates memory and plasticity via SIRT1 and miR-134. Nature 466:1105-1109. CrossRef Medline

Kaeberlein M, McVey M, Guarente L (1999) The SIR2/3/4 complex and SIR2 alone promote longevity in Saccharomyces cerevisiae by two different mechanisms. Genes Dev 13:2570-2580. CrossRef Medline

Kalivas PW (2009) Perspective: the manifest destiny of cocaine research. Neuropsychopharmacology 34:1089-1090. CrossRef Medline

Kim D, Nguyen MD, Dobbin MM, Fischer A, Sananbenesi F, Rodgers JT, Delalle I, Baur JA, Sui G, Armour SM, Puigserver P, Sinclair DA, Tsai LH (2007) SIRT1 deacetylase protects against neurodegeneration in models for Alzheimer's disease and amyotrophic lateral sclerosis. EMBO J 26: 3169-3179. CrossRef Medline

Kouzarides T (2007) Chromatin modifications and their function. Cell 128: 693-705. CrossRef Medline

Kumar A, Choi KH, Renthal W, Tsankova NM, Theobald DE, Truong HT, Russo SJ, Laplant Q, Sasaki TS, Whistler KN, Neve RL, Self DW, Nestler EJ (2005) Chromatin remodeling is a key mechanism underlying cocaineinduced plasticity in striatum. Neuron 48:303-314. CrossRef Medline

LaPlant Q, Vialou V, Covington HE 3rd, Dumitriu D, Feng J, Warren BL, Maze I, Dietz DM, Watts EL, Iñiguez SD, Koo JW, Mouzon E, Renthal W, Hollis F, Wang H, Noonan MA, Ren Y, Eisch AJ, Bolaños CA, Kabbaj M, et al. (2010) Dnmt3a regulates emotional behavior and spine plasticity in the nucleus accumbens. Nat Neurosci 13:11371143. CrossRef Medline

Levine A, Huang Y, Drisaldi B, Griffin EA, Jr., Pollak DD, Xu S, Yin D, Schaffran C, Kandel DB, Kandel ER (2011) Molecular mechanism for a gateway drug: epigenetic changes initiated by nicotine prime gene expression by cocaine. Sci Transl Med 3:107ra109. CrossRef Medline

Li H, Rajendran GK, Liu N, Ware C, Rubin BP, Gu Y (2007) SirT1 modulates the estrogen-insulin-like growth factor-1 signaling for postnatal development of mammary gland in mice. Breast Cancer Res 9:R1. CrossRef Medline

Livak KJ, Schmittgen TD (2001) Analysis of relative gene expression data using real-time quantitative PCR and the 2(-Delta Delta $\mathrm{C}(\mathrm{T})$ ) Method. Methods 25:402-408. CrossRef Medline

Lobo MK, Covington HE 3rd, Chaudhury D, Friedman AK, Sun H, DamezWerno D, Dietz DM, Zaman S, Koo JW, Kennedy PJ, Mouzon E, Mogri M, Neve RL, Deisseroth K, Han MH, Nestler EJ (2010) Cell type-specific loss of BDNF signaling mimics optogenetic control of cocaine reward. Science 330:385-390. CrossRef Medline

Maze I, Covington HE 3rd, Dietz DM, LaPlant Q, Renthal W, Russo SJ, Mechanic M, Mouzon E, Neve RL, Haggarty SJ, Ren Y, Sampath SC, Hurd YL, Greengard P, Tarakhovsky A, Schaefer A, Nestler EJ (2010) Essential role of the histone methyltransferase G9a in cocaine-induced plasticity. Science 327:213-216. CrossRef Medline

Maze I, Feng J, Wilkinson MB, Sun H, Shen L, Nestler EJ (2011) Cocaine dynamically regulates heterochromatin and repetitive element unsilencing in nucleus accumbens. Proc Natl Acad Sci U S A 108:3035-3040. CrossRef Medline

McClung CA, Nestler EJ (2003) Regulation of gene expression and cocaine reward by CREB and DeltaFosB. Nat Neurosci 6:1208-1215. CrossRef Medline

Michán S, Sinclair D (2007) Sirtuins in mammals: insights into their biological function. Biochem J 404:1-13. CrossRef Medline

Michán S, Li Y, Chou MM, Parrella E, Ge H, Long JM, Allard JS, Lewis K, Miller M, Xu W, Mervis RF, Chen J, Guerin KI, Smith LE, McBurney MW, Sinclair DA, Baudry M, de Cabo R, Longo VD (2010) SIRT1 is essential for normal cognitive function and synaptic plasticity. J Neurosci 30:9695-9707. CrossRef Medline

Nestler EJ (2008) Review. Transcriptional mechanisms of addiction: role of DeltaFosB. Philos Trans R Soc Lond B Biol Sci 363:3245-3255. CrossRef Medline

Peakman MC, Colby C, Perrotti LI, Tekumalla P, Carle T, Ulery P, Chao J, Duman C, Steffen C, Monteggia L, Allen MR, Stock JL, Duman RS, McNeish JD, Barrot M, Self DW, Nestler EJ, Schaeffer E (2003) Inducible, brain region specific expression of a dominant negative mutant of c-Jun in transgenic mice decreases sensitivity to cocaine. Brain Res 970:73-86. CrossRef Medline

Renthal W, Nestler EJ (2008) Epigenetic mechanisms in drug addiction. Trends Mol Med 14:341-350. CrossRef Medline

Renthal W, Carle TL, Maze I, Covington HE 3rd, Truong HT, Alibhai I, Kumar A, Montgomery RL, Olson EN, Nestler EJ (2008) $\Delta$ FosB mediates epigenetic desensitization of the c-fos gene after chronic amphetamine exposure. J Neurosci 28:7344-7349. CrossRef Medline

Renthal W, Kumar A, Xiao G, Wilkinson M, Covington HE 3rd, Maze I, Sikder D, Robison AJ, LaPlant Q, Dietz DM, Russo SJ, Vialou V, Chakravarty S, Kodadek TJ, Stack A, Kabbaj M, Nestler EJ (2009) Genomewide analysis of chromatin regulation by cocaine reveals a role for sirtuins. Neuron 62:335-348. CrossRef Medline

Robinson TE, Kolb B (2004) Structural plasticity associated with exposure to drugs of abuse. Neuropharmacology 47 [Suppl 1]:33-46. CrossRef Medline

Robinson TE, Berridge KC (2008) Review. The incentive sensitization theory of addiction: some current issues. Philos Trans R Soc Lond B Biol Sci 363:3137-3146. CrossRef Medline

Robison AJ, Nestler EJ (2011) Transcriptional and epigenetic mechanisms of addiction. Nat Rev Neurosci 12:623-637. CrossRef Medline

Robison AJ, Vialou V, Mazei-Robison M, Feng J, Kourrich S, Collins M, Wee SM, Koob G, Turecki G, Neve R, Thomas M, Nestler EJ (2013) Behavioral and structural responses to chronic cocaine require a feed-forward loop involving $\Delta$ FosB and CaMKII in the nucleus accumbens shell. J Neurosci 33:4295-4307. CrossRef Medline

Rogge GA, Wood MA (2013) The role of histone acetylation in cocaineinduced neural plasticity and behavior. Neuropsychopharmacology 38 : 94-110. CrossRef Medline

Russo SJ, Wilkinson MB, Mazei-Robison MS, Dietz DM, Maze I, Krishnan V, Renthal W, Graham A, Birnbaum SG, Green TA, Robison B, Lesselyong A, Perrotti LI, Bolaños CA, Kumar A, Clark MS, Neumaier JF, Neve RL, Bhakar AL, Barker PA, et al. (2009) Nuclear factor- $\kappa$ B signaling regulates neuronal morphology and cocaine reward. J Neurosci 29:35293537. CrossRef Medline 
Russo SJ, Dietz DM, Dumitriu D, Morrison JH, Malenka RC, Nestler EJ (2010) The addicted synapse: mechanisms of synaptic and structural plasticity in nucleus accumbens. Trends Neurosci 33:267-276. CrossRef Medline

Sasaki T, Maier B, Bartke A, Scrable H (2006) Progressive loss of SIRT1 with cell cycle withdrawal. Aging Cell 5:413-422. CrossRef Medline

Sassone-Corsi P (2012) Minireview: NAD+, a circadian metabolite with an epigenetic twist. Endocrinology 153:1-5. CrossRef Medline

Shen L, Shao NY, Liu X, Maze I, Feng J, Nestler EJ (2013) diffReps: detecting differential chromatin modification sites from ChIP-seq data with biological replicates. PLoS One 8:e65598. CrossRef Medline

Wang L, Lv Z, Hu Z, Sheng J, Hui B, Sun J, Ma L (2010) Chronic cocaineinduced $\mathrm{H} 3$ acetylation and transcriptional activation of CaMKIIalpha in the nucleus accumbens is critical for motivation for drug reinforcement. Neuropsychopharmacology 35:913-928. CrossRef Medline

Winstanley CA, LaPlant Q, Theobald DE, Green TA, Bachtell RK, Perrotti LI, DiLeone RJ, Russo SJ, Garth WJ, Self DW, Nestler EJ (2007) $\Delta$ FosB induction in orbitofrontal cortex mediates tolerance to cocaine-induced cognitive dysfunction. J Neurosci 27:10497-10507. CrossRef Medline

Yang Y, Fu W, Chen J, Olashaw N, Zhang X, Nicosia SV, Bhalla K, Bai W (2007) SIRT1 sumoylation regulates its deacetylase activity and cellular response to genotoxic stress. Nat Cell Biol 9:1253-1262. CrossRef Medline

Zachariou V, Bolanos CA, Selley DE, Theobald D, Cassidy MP, Kelz MB, Shaw-Lutchman T, Berton O, Sim-Selley LJ, Dileone RJ, Kumar A, Nestler EJ (2006) $\Delta$ FosB: an essential role for $\Delta$ FosB in the nucleus accumbens in morphine action. Nat Neurosci 9:205-211. CrossRef Medline 